\title{
Optimization of DNA extraction and PCR protocols for phylogenetic analysis in Schinopsis spp. and related Anacardiaceae
}

(2) CrossMark

Virginia Y. Mogni ${ }^{1,2 *}$, Mariano A. Kahan³, Luciano Paganucci de Queiroz ${ }^{4}$, José L. Vesprini 1,2, Juan Pablo A. Ortiz ${ }^{1,2}$ and Darién E. Prado ${ }^{1,2}$

\begin{abstract}
The Anacardiaceae is an important and worldwide distributed family of ecological and socio-economic relevance. Notwithstanding that, molecular studies in this family are scarce and problematic because of the particularly high concentration of secondary metabolites-i.e. tannins and oleoresins - that are present in almost all tissues of the many members of the group, which complicate the purification and amplification of the DNA. The objective of this work was to improve an available DNA isolation method for Schinopsis spp. and other related Anacardiaceae, as well as the PCR protocols for DNA amplification of the chloroplast trnL-F, rps 16 and ndhF and nuclear ITS-ETS fragments. The modifications proposed allowed the extraction of 70-120 $\mu \mathrm{g}$ of non-degraded genomic DNA per gram of dry tissue that resulted useful for PCR amplification. PCR reactions produced the expected fragments that could be directly sequenced. Sequence analyses of amplicons showed similarity with the corresponding Schinopsis accessions available at GenBank. The methodology presented here can be routinely applied for molecular studies of the group aimed to clarify not only aspects on the molecular biology but also the taxonomy and phylogeny of this fascinating group of vascular plants.
\end{abstract}

Keywords: Anacardiaceae, DNA isolation, Phylogeny, Schinopsis, Sequencing

\section{Background}

The Anacardiaceae is a cosmopolitan family including 81 genera and approximately 800 species (Pell et al. 2011). Many genera are important for having edible fruits (Anacardium, Mangifera, Pistacia, Sclerocarya, Spondias), ornamental use (Cotinus, Rhus, Schinus), or quality timber (Astronium, Schinopsis). Some genera have resiniferous channels accumulating tannins, phenolic compounds and oils that increase the wood resistance.

The South American small genus Schinopsis Engl. is economically important given its extremely tough and durable timber. Its species have ecological relevance since they are usually forest dominants (Barberis et al. 2012). Although a new species was recently described (Mogni

\footnotetext{
*Correspondence: virginia.mogni@unr.edu.ar

${ }^{1}$ Facultad de Ciencias Agrarias, Universidad Nacional de Rosario, Campo Experimental Villarino, S2125ZAA Zavalla, Santa Fe, Argentina

Full list of author information is available at the end of the article
}

et al. 2014), the taxonomy and phylogeny of Schinopsis is not well resolved. Classical studies based on morphology have limitations due to low variation between species and the existence of interspecific hybrids (Mogni 2015). Therefore, integrating morphological with molecular approaches could help resolve this issue.

Molecular sequence data have revolutionized phylogenetic analysis. In vascular plants, most sequenced-based molecular phylogenetic studies rely on DNA regions of the plastid genome, and on internal (or external) transcribed spacers (ITS/ETS) regions of the $18 \mathrm{~S}-5.8 \mathrm{~S}-26 \mathrm{~S}$ nuclear ribosomal cistron. The chloroplast trnL-F, $n d h \mathrm{~F}$ and rps 16 regions and nuclear ITS and ETS have been used in Anacardiaceae (Pell 2004; Nie et al. 2009; Xie et al. 2014; Weeks et al. 2014; Machado et al. 2015) and related families such as Burseraceae (Becerra and Venable 1999; Weeks et al. 2014) and Meliaceae (Koenen et al. 2015). Nevertheless, few Schinopsis accessions have been included in those studies, due to the presence of 
tannins and oleoresins that strongly affect DNA purification, PCR amplification and sequencing, as it happens in other Anacardiaceae (Pell pers. com.) or other plant groups (Permingeat et al. 1998). Such is the Spondias case, reported to be exceedingly difficult to purify and amplify DNA even from fresh leaf samples (Mitchell and Daly 2015).

Several methods for DNA extraction of plants with high phenolic contents were developed (e.g. Porebski et al. 1997; Permingeat et al. 1998). Nevertheless, in Schinopsis spp. attempts carried out using this kind of protocols were unsuccessful (Kahan 2007). The lack of specific methodology for these species has lead to uncertain results and consequently delayed the application of molecular analyses involving numerous accessions and/ or species. Moreover, due to the wide geographic distribution of these species, the utilization of herbarium specimens or silica gel-dried material is mandatory.

The aim of this work was to develop an adapted protocol for routine isolation of DNA and to optimize a PCR protocol for amplifying chloroplast and nuclear regions useful for molecular phylogenetic analysis in Schinopsis spp. and other Anacardiaceae.

\section{Results and discussion}

Briefly, the modifications introduced to the protocol described by Permingeat et al. (1998), that allowed the isolation of total DNA of all species tested were the following: the decrease of the initial quantity of plant material (20-25 vs. $500-1000 \mathrm{mg})$; the addition of sterile sand (or liquid nitrogen in the Eppendorf tubes) for disrupting leaf tissue and create the lysate; the extension in the incubation time and the temperature increment (150 $\mathrm{min}$ at $75{ }^{\circ} \mathrm{C}$ vs. $60 \mathrm{~min}$ at $60^{\circ} \mathrm{C}$ ) of the Extraction Buffer; the duplication of the chloroform step for protein removal and the final precipitation with Ethanol in presence of $5 \% \mathrm{~V} / \mathrm{V} \mathrm{NaCl} 5 \mathrm{M}$ (instead of $\mathrm{NaAc} 3 \mathrm{M}$ pH 5.2). The result of the extraction methods are shown in Fig. 1. The modified protocol produced clear bands of high molecular weight corresponding to the total DNA in most of the accessions (38/41), although some samples showed smearing consistent with partially degraded DNA (Fig. 1a). The assays performed with the DNeasy Plant Mini Kit (control) showed similar results and allowed the extraction of the 12 samples tested as well, and less smearing was observed (Fig. 1b). Comparison by eye of ethidium bromide fluorescence produced by the samples to the Lambda DNA and spectrophotometric quantification showed values ranging from 70 to $120 \mu \mathrm{g}$ of DNA per gram of tissue (vs. 75-130 $\mu \mathrm{g}$ obtained with the control, see Fig. 1b), indicating a relative good yield and the presence of high molecular weight DNA, and that the samples can be used directly for PCR reactions.
PCR assays performed using the DNA preparations diluted $1 / 10$ allowed the generation of all fragments tested. The addition of BSA 1/1000; $\mathrm{MgCl}_{2} 5 \mathrm{mM}$ and DMSO $1 \mathrm{M}$ (for ETS and ITS) in the PCR mixture was crucial for amplification success, as it was previously reported (Savolainen et al. 1995; Baldwin et al. 1995; Särkinen et al. 2012). This is probably because BSA has a high content of lysine; it joins phenolic compounds when added to the PCR mix, avoiding Taq polymerase inactivation (Kreader 1996). On the other hand, DMSO acts by relaxing the typical secondary structure of nuclear ribosomal regions during amplification (Álvarez and Wendel 2003). Chloroplast regions trnL-F, rps 16 and $n d h \mathrm{~F}$ resulted in amplicons of 400,900 and 650 bp respectively (Fig. 2a-c). On the other hand, the amplification of the nuclear region ETS resulted in a fragment of approximately 300 bp (Fig. 3a), and ITS2 in 200-300 bp (Fig. 3b).

Amplification products corresponding to each fragment from the different accessions were directly sequenced. Most sequences showed similarity with Schinopsis accessions available at GenBank, particularly to those obtained by Pell (2004). Chloroplast regions displayed high scores, with E-values and identities of 0.0 and $98 \%$ respectively for trnL-F; 0.0 and $99 \%$ for rps 16 and 0.0 and $99 \%$ for $n d h F$. Likewise, nucleic sequences showed E-values and identities of $1 \mathrm{E}^{-129}-99 \%$ for ETS and $2 \mathrm{E}^{-94}-90 \%$ for ITS2. Consequently, the amplicons corresponded to both expected chloroplast and nuclear hypervariable regions of Schinopsis.

\section{Conclusions}

Based on Permingeat et al. (1998), we developed an adapted new protocol to isolate DNA from dried Schinopsis leaves. Our experiment revealed that the modifications introduced (see Protocol, "Methods" section) were favourable to improve the DNA isolation. Although some degradation was observed, sufficient quantity of high molecular weight DNA was available in most samples. Moreover, the quality of the DNA isolated was sufficient for PCR amplification. Interestingly, PCR products could be sequenced directly, without necessity of isolation, purification and cloning. Most sequences matched with the corresponding subject in the data bank, thus indicating its specificity.

The results presented in this work have an interesting potential use for molecular studies of Anacardiaceae, especially within the Schinopsis genus, which has high concentrations of inhibitors (Mitchell 1990). Therefore, this new optimized protocol has the double advantage of circumventing DNA purification and at the same time being affordable, and thus helping to find a feasible solution to the notable difficulties to purify and amplify DNA from some Anacardiaceae (Pell 2004; Mitchell and Daly 2015). 


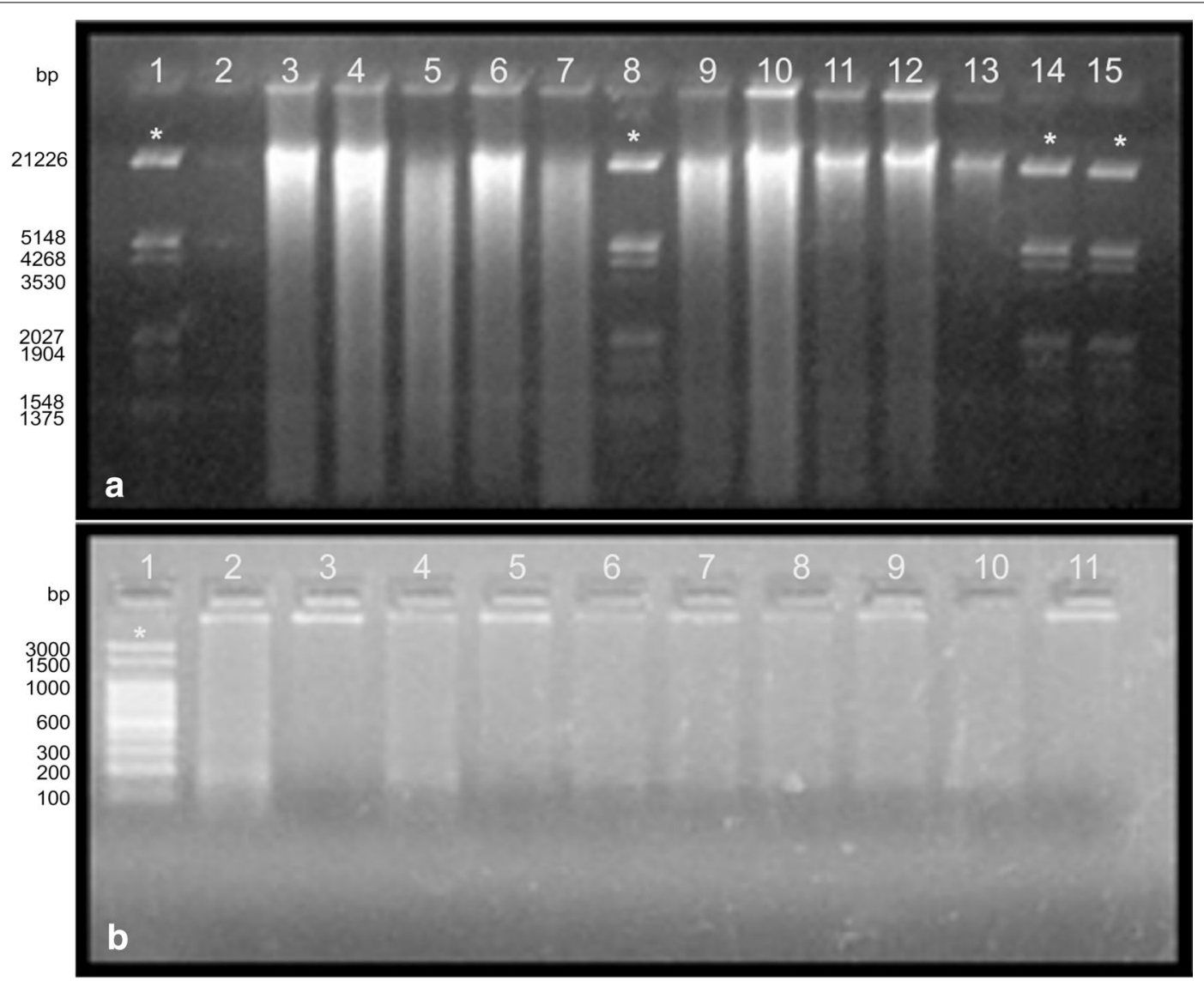

Fig. $10.8 \%$ Agarose gel electrophoresis depicting results of DNA extraction of some accessions of Schinopsis spp. and related species. a DNA extracted with the optimized protocol. Lanes 1, 2, 8, 14 and 15 molecular marker (Lambda EcoRI/HindIII), 3 and 4 S. Iorentzii, 5 and 6 S. marginata, 7 Lithraea molleoides, 9-13 S. brasiliensis. b DNA extracted with the DNAEasy Plant Mini Kit (Quiagen Inc. Valencia, CA) used as control. 1 Molecular weight marker (100 bp DNA Ladder), 2-11 different specimens of S. brasiliensis (asterisk reference bands of the marker)

\section{Methods}

\section{Plant material}

A total of 41 specimens were used. The plant material included 36 samples of Schinopsis spp. and five outgroups (see Additional file 1). These materials were selected covering natural populations of Argentina, Brazil, Bolivia, Paraguay and Peru.

\section{DNA extraction}

Silica gel dried and herbarium specimen leaves were used for DNA isolation. The DNA extraction protocol was based on previous reports (Permingeat et al. 1998; Kahan 2007) with the modifications listed below. Moreover, 12 samples were extracted using the DNeasy Plant Mini Kit (Qiagen Inc., Valencia CA) as control. In order to prevent allergic reactions (dermatitis) due to the skin-irritating components, it is recommended to protect own skin in all steps of the procedure, particularly when sampling and grinding the material.

\section{Total DNA extraction protocol}

1. Ground $20-25 \mathrm{mg}$ of plant tissue in $1.5 \mathrm{ml}$ Eppendorf tubes using polypropylene micropestles by hand or with the aid of a mechanic disruptor, or in a mortar and pestle with a pinch of sterile sand. $(*)$

2. Transfer the powder to a $1.5 \mathrm{ml}$ Eppendorf tubes containing $1 \mathrm{ml}$ Extraction Buffer (Tris $\mathrm{HCl} 100 \mathrm{mM}$ $\mathrm{pH}$ 8; $\mathrm{NaCl} 1.4 \mathrm{M}$; EDTA $20 \mathrm{mM}$; glucose $0.5 \mathrm{M}$; $\mathrm{CTAB}$-cetyltrimethylammonium bromide-2 \%) preheated at $75^{\circ} \mathrm{C}$.

3. Homogenize and incubate at $75{ }^{\circ} \mathrm{C}$ for $150 \mathrm{~min}$ by vortering every $30 \mathrm{~min} .\left(^{*}\right)$

4. Centrifuge at $10,000 \mathrm{rpm}$ for $10 \mathrm{~min}$ at room temperature, and transfer approximately $700 \mu$ of the upper liquid layer to a $1.5 \mathrm{ml}$ Eppendorf tube. $\left(^{*}\right)$

5. Add 1 volume of chloroform and produce an emulsion by gently shaking the tube for $10 \mathrm{~min}$.

6. Centrifuge at $10,000 \mathrm{rpm}$ for $10 \mathrm{~min}$ at room temperature. 


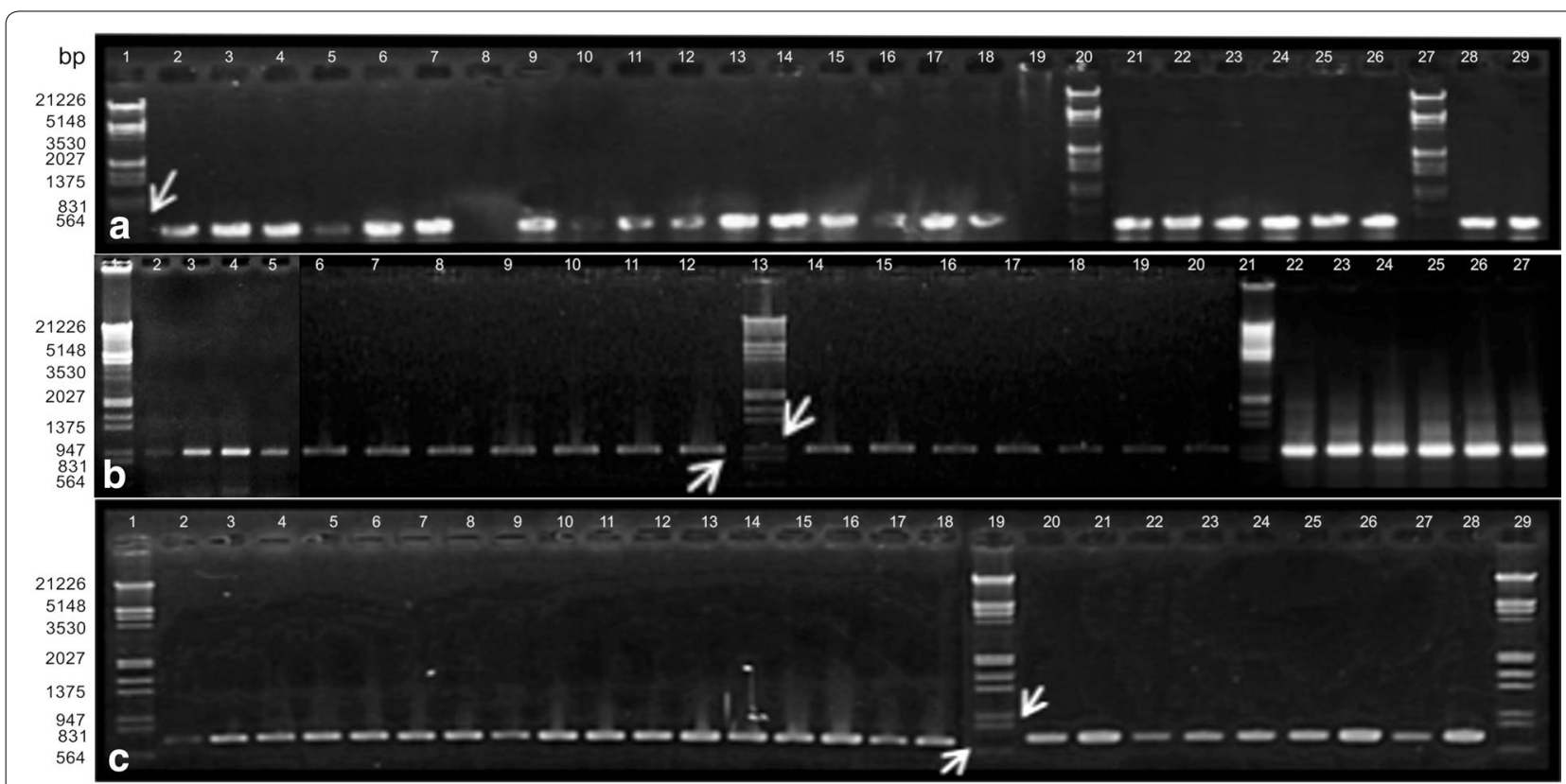

Fig. $21.5 \%$ Agarose gel electrophoresis of PCR products of several accessions of Schinopsis spp. and related species. a trnL-F amplified in two parts. Lanes 1, 20, 27 molecular marker, 2-5 S. boqueronensis, 6-7, 9 S. cornuta, 10 S. peruviana, 11-14 S. heterophylla, 15-18, 21 S. brasiliensis, 22-23 S. marginata, 24 S. Iorentzii, 25-26 S. brasiliensis, 28-29 Astronium urundeuva and Apterokarpos gardneri, and 8, 19 without sample. b rps 16. Lanes 1, 13 and 21 molecular marker, 2 S. peruviana, 3-6 S. heterophylla, 5-9, 14-15 S. brasiliensis, 10-11 S. marginata, 12 S. Iorentzii, 16-17 Astronium urundeuva and Apterokarpos gardneri, 18-19 S. balansae, 20 S. lorentzii, 22-24 S. boqueronensis, 25-27 S. cornuta. c ndhF. Lanes 1, 19 and 29 molecular marker, 11, 12, 17-19 Astronium urundeuva, Apterokarpos gardneri, Lithraea molleoides, Loxopterygium grisebachii and Schinus areira; other lanes, Schinopsis spp. Arrows indicate the reference bands of the marker Lambda EcoRI/Hindlll (564 bp in a, 947 and 831 in $\mathbf{b}$ and 831 and 564 in c) to estimate the amplicons size

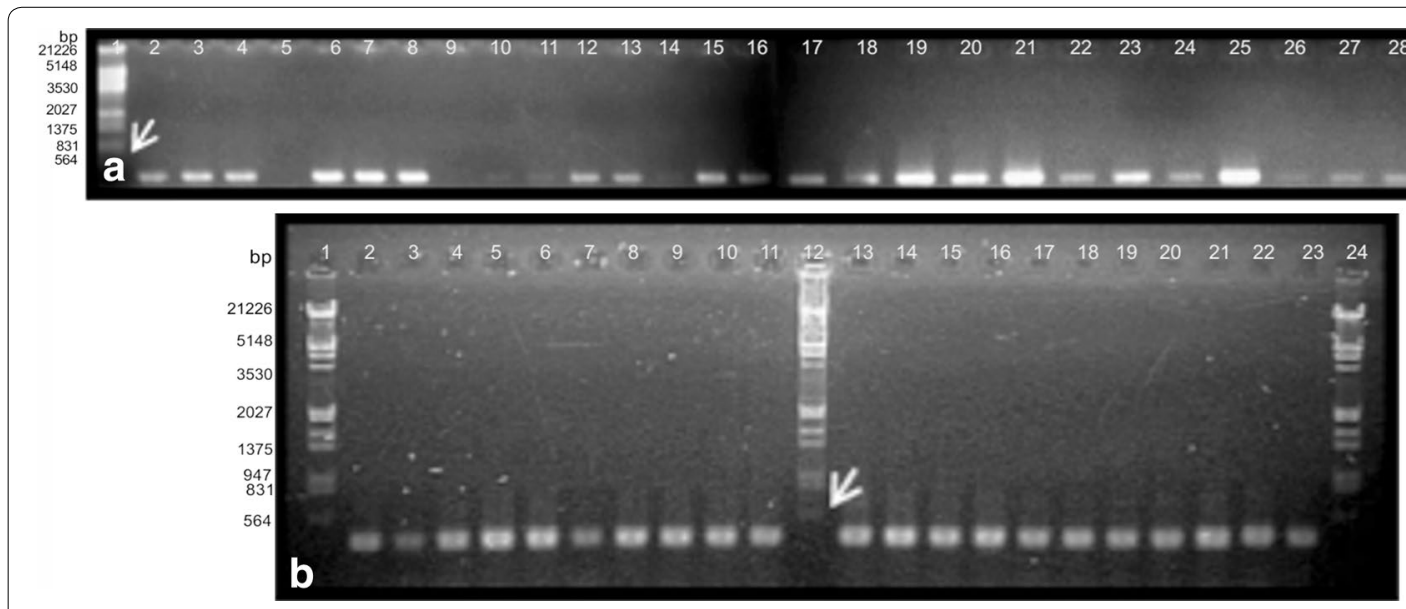

Fig. $31.5 \%$ agarose gel electrophoresis of PCR products of some accessions of Schinopsis spp. and related species. a ETS. Lane 1 molecular marker, 2-5 S. boqueronensis, 6-8, S. cornuta, 9, S. peruviana, 10-13, S. heterophylla, 14-18, 21, 22, S. brasiliensis, 19, 20, S. marginata, 21, 27, 28 S. lorentzii, 23, 24, 29-31 Astronium urundeuva, Apterokarpos gardneri, Lithraea molleoides, Loxopterygium grisebachii and Schinus areira. b ITS2. Line 1, 12, 24 molecular marker, 2 S. cornuta, 3-6 S. heterophylla, 7-10, 15, 16 S. brasiliensis, 11, 12 S. heterophylla, 13, 18, 19, S. Iorentzii, 20-22, Lithraea molleoides, Loxopterygium grisebachii and Schinus areira. Arrows indicate the reference bands of the marker Lambda EcoRI/HindIII (564 bp in $\mathbf{a}$ and $\mathbf{b}$ ) to estimate the amplicons size 
7. Repeat steps 5 and 6 , but with shaking for 5 min. (*)

8. Recover $500 \mu \mathrm{l}$ of the supernatant and transfer to a new $1.5 \mathrm{ml}$ tube. Precipitate DNA with isopropanol 0.8 vol for $\mathbf{1 2} \mathbf{~ h}$ at $-20{ }^{\circ} \mathrm{C}$.

9. Precipitate DNA by centrifugation at $10,000 \mathrm{rpm}$ for $\mathbf{1 5} \mathbf{~ m i n}$ at room temperature and discard the upper liquid layer.

10. Wash the precipitate with $500 \mu \mathrm{l}$ of ethanol $75 \%$ and centrifuge $15 \mathrm{~min}$ at 10,000 rpm, discarding the supernatant. $(*)$

11. Dry the DNA in stove at $37^{\circ} \mathrm{C}$, and then resuspend the pellet in $50 \mu \mathrm{l}$ of TE buffer (Tris $\mathrm{HCl} 100 \mathrm{mM} \mathrm{pH}$ 8; EDTA $1 \mathrm{mM})$.

12. Add $0.5 \mu \mathrm{l}$ of RNase A (Invitrogen) and incubate for $60 \mathrm{~min}$ at $37^{\circ} \mathrm{C}$ to digest the RNA.

13. Precipitate the DNA by adding first $5 \% \mathrm{~V} / \mathrm{V}$ of $\mathrm{NaCl}$ $5 \mathrm{M}$ and then 2 volumes of cold ethanol $100 \%$ for $12 \mathrm{~h}$ at $-20{ }^{\circ} \mathrm{C} .(*)$

14. Centrifuge at $10,000 \mathrm{rpm}$ for $\mathbf{1 5} \mathbf{~ m i n}$ at room temperature.

15. Do a second wash with $500 \mu$ l of cold ethanol $75 \%$ $\mathrm{V} / \mathrm{V}$, and discard the supernatant. (*)

16. Dry well the DNA in stove at $37{ }^{\circ} \mathrm{C}$, and then dissolve in $50 \mu \mathrm{l}$ of sterile and distilled water.

(*) Steps substantially modified; some features are in bold type to indicate the parts of the steps that were partially modified from Permingeat et al. (1998).
After purification, the integrity of the DNA was tested by electrophoresis in $0.8-1 \%$ agarose gel in TAE $1 \times$ buffer, at $60 \mathrm{~mA}$ for approximately $2.30 \mathrm{~h}$. The DNA was stained with ethidium bromide $(10 \mu \mathrm{g} / \mathrm{ml})$ and visualized under a UV transilluminator. The DNA yield was estimated by spectrophotometric analysis and by comparing the fluorescence intensity of each sample to $100 \mathrm{ng}$ of Lambda (EcoRI/HindIII) marker (Promega, USA) (Fig. 1a) or $325 \mathrm{ng}$ of $100 \mathrm{bp}$ DNA Ladder (Promega) (Fig. 1b) as standard.

\section{PCR amplification reactions}

Both chloroplast and nuclear regions were amplified from total DNA following the PCR protocols described by Pell (2004). To amplify trnL-F, rps 16 and $n d h \mathrm{~F}$ regions primers in Taberlet et al. (1991), Oxelman et al. (1997) and Olmstead and Sweere (1994) were used. On the other hand, for nuclear markers, the primers reported by Weeks (2003) and Baldwin and Markos (1998) were employed for ETS regions, and the primers in White et al. (1990) and Wurdack in Pell (2004) respectively were applied to amplify ITS2 (see primers details in Additional file 2).

PCR amplifications were carried out in $50 \mu \mathrm{l}$ final volume reactions (Table 1 ) using only the DNA samples obtained with the modified protocol, diluted $1 / 10$ in order to reduce inhibitors concentration (Savolainen et al. 1995). PCR steps, for each reaction, are summarized

Table 1 List of reagents and PCR steps to amplify chloroplast regions trnL-F, rps16, ndhF and nuclear regions ETS and ITS2

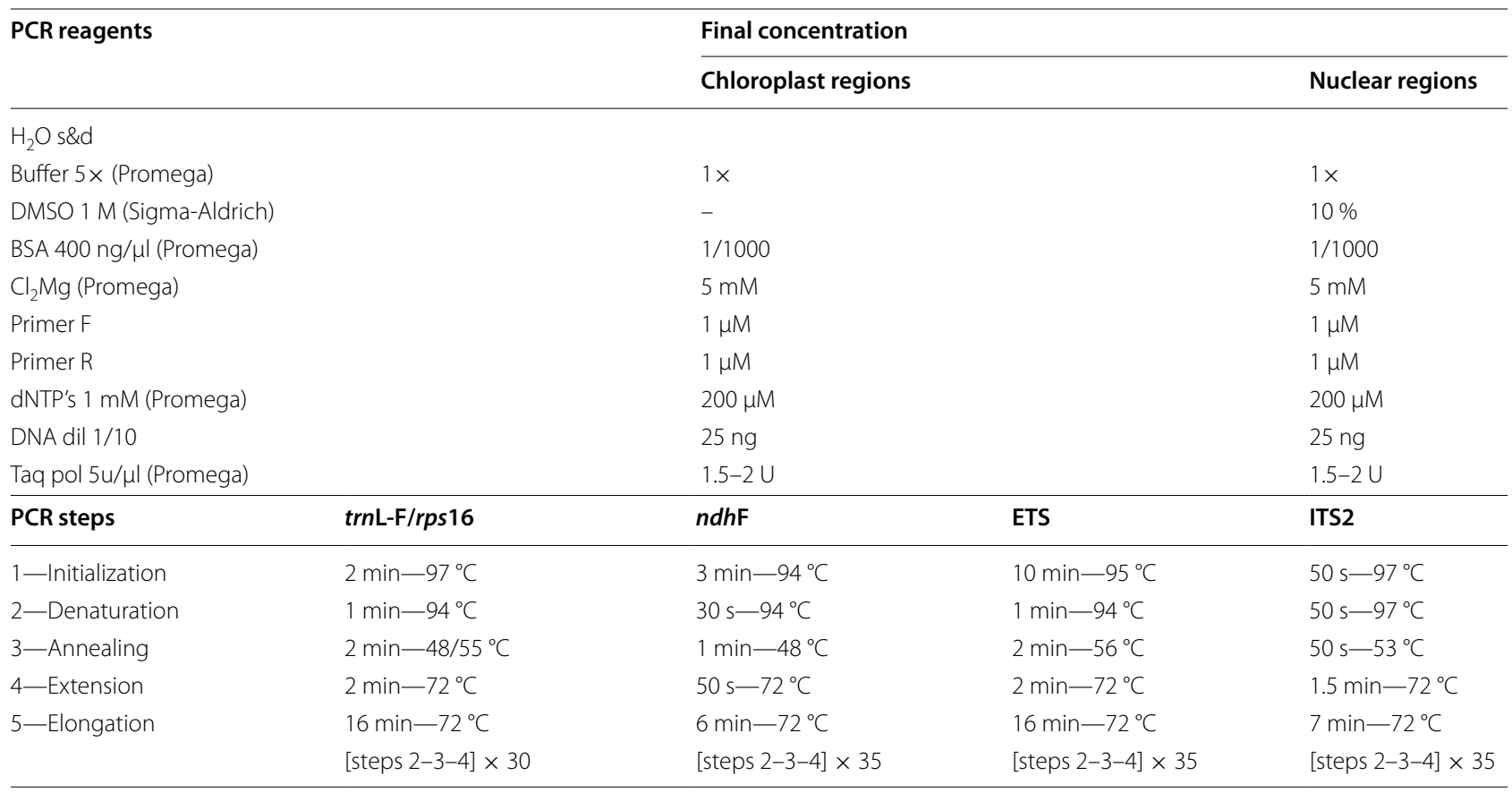


in Table 1. For trnL-F, the thermal cycle consisted on 2 min at $97{ }^{\circ} \mathrm{C}$ for one cycle, followed by 30 cycles of denaturation at $94{ }^{\circ} \mathrm{C}$ for $1 \mathrm{~min}$, annealing at $48{ }^{\circ} \mathrm{C}$ for $2 \mathrm{~min}$ and $72{ }^{\circ} \mathrm{C}$ for $2 \mathrm{~min}$ and finally $16 \mathrm{~min}$ at $72{ }^{\circ} \mathrm{C}$ was allowed to the dissociation step. Similar parameters were used for rps16, except for the annealing temperature, which was $55^{\circ} \mathrm{C}$ (modified from Pell 2004). For $n d h \mathrm{~F}$, we followed the parameters detailed in Davis et al. (2002) i.e.: an initial denaturation of $3 \mathrm{~min}$ at $94{ }^{\circ} \mathrm{C}$, then 35 cycles of $94{ }^{\circ} \mathrm{C}$ for $30 \mathrm{~s}, 48^{\circ} \mathrm{C}$ for $1 \mathrm{~min}$ and $72^{\circ} \mathrm{C}$ for $50 \mathrm{~s}$, and a final elongation of $6 \mathrm{~min}$ at $72{ }^{\circ} \mathrm{C}$. Nuclear genes segments were amplified using the following parameters: $10 \mathrm{~min}$ at $95^{\circ} \mathrm{C}$, followed by 35 cycles of $1 \mathrm{~min}$ at $94{ }^{\circ} \mathrm{C}$, 2 min at $56^{\circ} \mathrm{C}$ and $2 \mathrm{~min}$ at $72{ }^{\circ} \mathrm{C}$, and finally $16 \mathrm{~min}$ at $72{ }^{\circ} \mathrm{C}$ for ETS and $50 \mathrm{~s}$ at $97{ }^{\circ} \mathrm{C}$ for one cycle, then 35 cycles of $50 \mathrm{~s}$ at $97{ }^{\circ} \mathrm{C}$, annealing for $50 \mathrm{~s}$ at $53^{\circ} \mathrm{C}$, and $1.50 \mathrm{~min}$ at $72{ }^{\circ} \mathrm{C}$, and $7 \mathrm{~min}$ at $72{ }^{\circ} \mathrm{C}$ for ITS2 (modified from Pell 2004).

For several samples, the amplification of rps 16 produced more than one PCR product. Consequently, the target amplicons were extracted from the agarose gel and purified using Wizard SV Gel and PCR Clean-Up System (Promega, Madison, WI, USA). Then they were re-amplified following the procedure described above.

\section{Sequencing of PCR amplicons and bioinformatics analysis} PCR products were sequenced at Macrogen (Seoul, South Korea; http://dna.macrogen.com/eng/). Each fragment was sequenced in both directions $\left(5^{\prime}-3^{\prime}\right.$ and $3^{\prime}-5^{\prime}$ ) employing the same primers used in the amplification reactions (see Additional file 2). The identity of the sequences obtained was confirmed by comparison with sequences available in the National Center for Biotechnology Information (NCBI; http://www. ncbi.nlm.nih.gov/) database. For each taxon and DNA region, forward $\left(5^{\prime}-3^{\prime}\right)$ and reverse $\left(3^{\prime}-5^{\prime}\right)$ sequences were assembled and checked for inaccurate base pairing using the Sequencher (v. 4.1, Gene Codes Corp.) free software.

\section{Additional files}

Additional file 1. List of taxa and specimens used in the study.

Additional file 2. List of PCR primers (5'-3') to amplify chloroplast and nuclear regions.

\footnotetext{
Authors' contributions

VYM and MAK collected the material in the field, carried out the molecular genetic studies and did the bioinformatic analysis. JPO and JLV participated in the design of the study and JPO also helped with the bioinformatic analysis. LPQ provided crucial support for collecting specimens, isolating DNA, and facilitated DNA samples from Brazilian material. DEP conceived the study, collected the material in the field, and participated in the design and coordination of the project. All authors read and approved the final manuscript.
}

\begin{abstract}
Author details
${ }^{1}$ Facultad de Ciencias Agrarias, Universidad Nacional de Rosario, Campo Experimental Villarino, S2125ZAA Zavalla, Santa Fe, Argentina. ${ }^{2}$ IICAR, Consejo Nacional de Investigaciones Científicas y Técnicas (CONICET-UNR), Zavalla, Argentina. ${ }^{3}$ SINERGIUM Biotech, Ruta Panamericana Km 38.7, 1619 Garin, Buenos Aires, Argentina. ${ }^{4}$ Departamento de Ciências Biológicas, Universidade Estadual de Feira de Santana, Av. Transnordestina, s/n, Novo Horizonte, Feira de Santana, Bahia 44036-900, Brazil.
\end{abstract}

\section{Acknowledgements}

Special thanks to M. Podio, L. Siena, J. Stein and the rest of the staff at Laboratorio de Biología Molecular, FCA-UNR in Argentina and to M. C. López Roberts from LAMOL-UEFS (Feira de Santana, Bahia, Brazil) for helping with laboratory activities. We also thank P. de Abreu Moreira for help and collaboration during fieldwork in Rio Grande do Norte and Ceará, Brasil, and likewise to L. J. Oakley, M. Vera Jiménez and G. González for their assistance while collecting in Paraguay. Our gratitude to R. T Pennington, who generously provided material from E herbarium specimens for this study and to S. Pell for her helpful suggestions on the development of the protocols. This work was supported by the CONICET-Consejo Nacional de Investigaciones Científicas y Técnicas and National University of Rosario, Argentina.

\section{Competing interests}

The authors declare that they have no competing interests.

Received: 3 December 2015 Accepted: 6 April 2016

Published online: 18 April 2016

\section{References}

Álvarez I, Wendel J (2003) Ribosomal ITS sequences and plant phylogenetic inference. Mol Phylogenet Evol 29:417-434

Baldwin B, Markos S (1998) Phylogenetic utility of the external transcribed spacer (ETS) of 18S-26S rDNA: congruence of ETS and ITS trees of Calycadenia (Compositae). Mol Phylogenet Evol 10:449-463

Baldwin B, Sanderson M, Porter J, Wojciechowski M, Campbell C, Donoghue M (1995) The ITS region of nuclear ribosomal DNA: a valuable source of evidence on angiosperm phylogeny. Ann Mo Bot Gard 82:247-277

Barberis IM, Mogni VY, Oakley LJ, Alzugaray C, Vesprini JL, Prado DE (2012) Biología de especies australes: Schinopsis balansae Engl. (Anacardiaceae). Kurtziana 37:59-86

Becerra J, Venable D (1999) Nuclear ribosomal DNA phylogeny and its implications for evolutionary trends in Mexican Bursera (Burseraceae). Am J Bot 86:1047-1057

Davis CC, Fritsch PW, Li J, Donoghue MJ (2002) Phylogeny and biogeography of Cercis (Fabaceae): evidence from nuclear ribosomal ITS and chloroplast ndhF sequence data. Syst Bot 27:289-302

Kahan MA (2007) Estudios de la biología reproductiva de Schinopsis balansae. Undergraduate dissertation, Universidad Nacional de Rosario

Koenen EJM, Clarkson JJ, Pennington TD, Chatrou LW (2015) Recently evolved diversity and convergent radiations of rainforest mahoganies (Meliaceae) shed new light on the origins of rainforest hyperdiversity. New Phytol 207:327-339

Kreader C (1996) Relief of amplification inhibition in PCR with bovine serum albumin or T4 gene 32 protein. Appl Environ Microbiol 62:1102-1106

Machado MC, Carvalho PCL, Van Den Berg C (2015) Domestication, hybridization, speciation, and the origins of an economically important tree crop of Spondias (Anacardiaceae) from the Brazilian Caatinga dry forest. Neodiversity 8:8-49

Mitchell J (1990) The poisonous Anacardiaceae genera of the world. Adv Econ Bot 8:103-129

Mitchell JD, Daly DC (2015) A revision of Spondias L. (Anacardiaceae) in the Neotropics. PhytoKeys 55:1-92

Mogni VY (2015) Estudio filogenético y biogeográfico del género Schinopsis (Anacardiaceae). Doctoral dissertation, Universidad Nacional de Rosario

Mogni VY, Oakley L, Vera Jiménez M, Prado DE (2014) A new tree species of Schinopsis (Anacardiaceae) from Paraguay and Bolivia. Phytotaxa 175:141-147 
Nie Z, Sun H, Meng Y, Wen J (2009) Phylogenetic analysis of Toxicodendron (Anacardiaceae) and its biogeographic implications on the evolution of north temperate and tropical intercontinental disjunctions. J Syst Evol 47:416-430

Olmstead R, Sweere J (1994) Combining data in phylogenetic systematics: an empirical approach using three molecular data sets in the Solanaceae. Syst Biol 43:467-481

Oxelman B, Lidén M, Berglund D (1997) Chloroplast rps16 intron phylogeny of the tribe Sileneae (Caryophyllaceae). Plant Syst Evol 206:393-410

Pell S (2004) Molecular systematics of the cashew family (Anacardiaceae). Ph.D. dissertation, Louisana State University

Pell S, Mitchell J, Miller A, Lobova T (2011) Anacardiaceae. In: Kubitzki K (ed) Flowering plants. Eudicots: Sapindales, Cucurbitales, Myrtaceae. Springer, Berlin, pp 7-50

Permingeat HR, Romagnoli MV, Vallejos RH (1998) A simple method for isolating high yield and quality DNA from cotton (Gossypium hirsutum L.) leaves. Plant Mol Biol Rep 16:1-6

Porebski S, Bailey LG, Baum BR (1997) Modification of a CTAB DNA extraction protocol for plants containing high polysaccharide and polyphenol components. Plant Mol Biol Rep 15:8-15

Särkinen T, Staats M, Richardson JE, Cowan RS, Bakker FT (2012) How to open the treasure chest? Optimising DNA extraction from herbarium specimens. PloS One 7:e43808. doi:10.1371/journal.pone.0043808
Savolainen V, Cuenoud P, Spichiger R, Martinez MDP, Crevecoeur M, Manen J-F (1995) The use of herbarium specimens in DNA phylogenetics: evaluation and improvement. Plant Syst Evol 197:87-98

Taberlet P, Gielly L, Pauton G, Bouvet J (1991) Universal primers for amplification of three non-coding regions of chloroplast DNA. Plant Mol Biol 17:1105-1109

Weeks A (2003) The molecular systematics and biogeography of the Burseraceae. Ph.D. dissertation, University of Texas

Weeks A, Zapata F, Pell S, Daly D, Mitchell J, Fine P (2014) To move or to evolve: contrasting patterns of intercontinental connectivity and climatic niche evolution in "Terebinthaceae" (Anacardiaceae and Burseraceae). Front Genet 5:409. doi:10.3389/fgene.2014.00409

White T, Bruns T, Lee S, Taylor J (1990) Amplification and direct sequencing of fungal ribosomal RNA genes for phylogenetics. In: Innis M, Gelfand DH, Sninsky JJ, White TJ (eds) PCR protocols: a guide to methods and applications. Academic Press, London, pp 315-322

Xie L, Yang ZY, Wen J, Li DZ, Yi TS (2014) Biogeographic history of Pistacia (Anacardiaceae), emphasizing the evolution of the Madrean-Tethyan and the eastern Asian-Tethyan disjunctions. Mol Phylogenet Evol 77:136-146

\section{Submit your manuscript to a SpringerOpen ${ }^{\circ}$ journal and benefit from:}

- Convenient online submission

- Rigorous peer review

- Immediate publication on acceptance

- Open access: articles freely available online

- High visibility within the field

- Retaining the copyright to your article

Submit your next manuscript at springeropen.com 